\title{
Evolution of chemical and biological characterization during agitated pile composting of flower waste
}

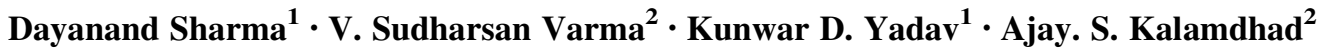

Received: 19 July 2016/ Accepted: 29 January 2017/Published online: 14 February 2017

(c) The Author(s) 2017. This article is published with open access at Springerlink.com

\begin{abstract}
Purpose Flower waste dumping in landfills and other disposal sites is causing major environmental issues due to its highly biodegradable nature. Instead, flower waste can be successfully composted for its higher nutrient value. Therefore, this study evaluated the pile composting of flower waste with different combinations of cow dung and saw dust to produce stabilized compost.

Methods Five agitated piles of flower waste mixture were formed in trapezoidal shape to perform the composting. Pile $\left(P_{0}\right)$ was a control experiment, which contained $100 \mathrm{~kg}$ flower waste. The quantity of flower waste mixture with cow dung and saw dust in the other Piles was a total of $100 \mathrm{~kg}$ i.e. $P_{1}$ (50:40:10) $\mathrm{kg}, P_{2}(60: 30: 10) \mathrm{kg}, P_{3}$ (70:20:10) $\mathrm{kg}$ and $P_{4}(80: 10: 10) \mathrm{kg}$, respectively.

Results Temperature above $50{ }^{\circ} \mathrm{C}$ was observed in all the piles except in $P_{0}$. Physico-chemical characteristics of compost showed a stabilized compost obtained by proportionate mix of flower waste, cow dung and saw dust. Pile $P_{2}$ was observed with $\mathrm{pH} 7.23$ and electrical conductivity $3.98 \mathrm{mS} \mathrm{cm}^{-1}$, total organic carbon $30.9 \%$, total nitrogen $2.31 \%$ and $\mathrm{C}: \mathrm{N}$ ratio 14 , thus a good proportion for compost amongst all the piles.

Conclusions Appropriate proportion of waste mixture played an important role in providing favorable conditions for the microbial transformation of flower waste to stabilized compost. Temperature influenced the growth of
\end{abstract}

Dayanand Sharma

dayanandsvnit@gmail.com

1 Civil Engineering Department, Sardar Vallabhbhai National Institute of Technology, Surat, Gujarat 395007, India

2 Civil Engineering Department, Indian Institute of Technology, Guwahati, Assam 781039, India microbes and maximum temperature was helpful in fast degradation of organic matter. Finally, flower waste with a combination of cow dung and saw dust was found to be successful during pile composting.

Keywords Agitated pile $\cdot \mathrm{C}: \mathrm{N}$ ratio $\cdot$ Co-composting · Flower waste $\cdot$ Nutrients

\section{Introduction}

In India, flowers are used for various purposes such as an offering to deities in religious places for worship, making garlands and bouquets, as decorative item for various religious ceremonies and social gatherings. As a result, about 300 MT of flower waste is generated per day and it has been found to be one of the major constituents of municipal solid waste (Singh et al. 2013). Most of the flower waste generated is disposed by directly dumping it in open land, water bodies. Alternatively, it is mixed with municipal solid waste for further treatment. Significant increase in leachate formation has been reported when flower waste/organic waste is mixed with municipal waste and is disposed off. Leachate production and percolation into ground water pollutes the ground of nearby landfill area (Varma and Kalamdhad 2014b). Flower waste disposed into rivers causes pollution of river water and is also harmful for both human and aquatic life. Thus, owing to the organic nature of flower waste and the significant presence of macro and micronutrients, composting offers a feasible solution to deal with flower waste.

Composting is defined as the natural biological decomposition of organic matter under self heating, aerobic and moist conditions to produce a stable nutrient enriched product which is used as organic manure (Bustamante et al. 
2009). Organic wastes that have high moisture content generate the leachate during the initial stage of composting and are responsible for decrease in temperature and development of the anaerobic condition. Leachate problem can be solved by addition of bulking agent which also allows free passage of air during the process of composting. Bulking agents also act as buffer against the organic acids produced during the initial stage of decomposition. They also help to maintain the pH 6-8 (Sánchez-Monedero et al. 2001). Typically used bulking agents for composting process are saw dust and dry leaves (Varma and Kalamdhad 2014b), newspaper (Ball et al. 2000), Wheat bran (Wang et al. 2012), Pumice (Wang et al. 2014; Wu et al. 2015) and wood shaving (Adhikari et al. 2009).

Several studies have been reported for agitated pile composting of organic waste such as vegetable waste (Varma and Kalamdhad 2014a), water hyacinth (Singh and Kalamdhad 2015), municipal solid waste (Iyengar and Bhave 2006), chicken litter (Gao et al. 2010), sewage sludge and pig faeces (Huang et al. 2004), food waste and saw dust (Zhou et al. 2014). However, there is limited literature available on the composting of flower waste with cow dung and saw dust as bulking agent.

Therefore, this study was focused on physico-chemical and biological characterization during composting of flower waste with cow dung and saw dust in different proportions. The best proportion for flower waste composting along with the addition of cow dung and saw dust was evaluated based on maturity and final micro-macronutrient concentration during the different stages of the composting process.

\section{Materials and methods}

\section{Feedstock}

This study was conducted in Environmental Engineering laboratory, SVNIT, Surat, Gujarat (India). Surat is situated on the bank of the river Tapti. It is located at $21.17^{\circ} \mathrm{N}$ latitude and $72.83^{\circ} \mathrm{E}$ longitude. Flower waste was collected from temples in Surat area, India. The debris (plastic, threads, incense sticks, coconut, etc.) was removed from flower waste manually. Large quantities of marigold were found along with rose, lotus, and siroi lily. Fresh cow dung was collected from a dairy farm in a nearby village. Saw dust was collected from a saw mill in Bhatar market. Table 1 shows the initial characteristics of feedstock.

\section{Agitated pile composting}

Identical agitated piles of trapezoidal shaped were prepared. The bottom length was $2700 \mathrm{~mm}$, width $450 \mathrm{~mm}$, height $500 \mathrm{~mm}$ and top width was $100 \mathrm{~mm}$ and $\mathrm{L} / \mathrm{W}$ ratio was kept as 6 with $100 \mathrm{~kg}$ of total weight. Cow dung and saw dust were mixed thoroughly followed by addition of the flower waste. The mixture was again made to blend properly. Studies were conducted in duplicate and average value was reported. Initially, all the piles were covered with plastic sheets for six days. The proportions of each pile are shown in Table 2.

All piles were manually turned upside down after three days. A sample of one $\mathrm{kg}$ was then collected from the top bottom and the centre at various locations of the pile and thoroughly mixed to form a homogenous sample. This process was repeated every three days for the first thirty days and then at an interval of seven days for the next thirty days. The collected samples were dried and crushed into fine powder. They were sieved through a $0.2 \mathrm{~mm}$ sieve and kept in desiccator for further analysis.

\section{Analysis of physico-chemical parameters}

The temperature was monitored throughout the composting period using digital thermometers. The temperature at different locations of each pile was measured and the average temperature was reported. Moisture content was monitored up to 30 days and after that moisture content was adjusted between 55 to $60 \%$, if needed; water was added on dry weight basis during the turning of piles. Gravimetric method was used for determining the moisture content of the sample after pile turning (BIS, 1982). For determining the $\mathrm{pH}$ and conductivity, $10 \mathrm{~g}$ dried sieved sample was diluted by $100 \mathrm{~mL}$ distilled water $(1: 10 \mathrm{w} / \mathrm{v})$ and kept through mixing in rotary shaker for $2 \mathrm{~h}$. Then the sample was left to be settled for half an hour for settling and finally filtered through the whatman filter paper no 42 (Singh and Kalamdhad 2016).

Total nitrogen was determined by Kjeldahl method. Ammonical nitrogen $\left(\mathrm{NH}_{4}{ }^{+}-\mathrm{N}\right)$ was determined by $\mathrm{KCl}$ extraction method followed by phenate method (APHA 2005). Volatile solids were determined by keeping the oven dried sieved sample in a muffle furnace for $550 \pm 5^{\circ} \mathrm{C}$ for $2 \mathrm{~h}$. The total organic carbon was calculated by dividing the volatile solids by 1.83 (Adhikari et al. 2009).

Fresh wet samples were used for the presence of $\mathrm{CO}_{2}$ and determination of germination index. The $\mathrm{CO}_{2}$ evolution rate was determined as described by Singh and Kalamdhad (2014). The Germination Index test was determined as described by Zhang and Sun (2015).

The macronutrients $(\mathrm{P}, \mathrm{K}, \mathrm{Na}, \mathrm{Ca}$ and $\mathrm{Mg}$ ) and the micronutrients $(\mathrm{Fe}, \mathrm{Mn}, \mathrm{Zn}$ and $\mathrm{Cu}$ ) present in the compost were analyzed according to Singh and Kalamdhad (2012). The sample was digested before analysis by heating $0.2 \mathrm{~g}$ dry sample with a ratio of $5: 1$ of $10 \mathrm{~mL} \mathrm{H}_{2} \mathrm{SO}_{4}$ and $\mathrm{HClO}_{4}$ at $300{ }^{\circ} \mathrm{C}$ for $2 \mathrm{~h}$. The digested sample was used for determining the total phosphorous present using stannous 
Table 1 Initial characteristics of feedstock material

\begin{tabular}{|c|c|c|c|}
\hline Parameters & Flowers waste & Cow dung & Saw dust \\
\hline Moisture content $(\%)$ & $82.01 \pm 0.7$ & $80.10 \pm 2.1$ & $16.71 \pm 0.7$ \\
\hline $\mathrm{pH}$ & $5.26 \pm 0.03$ & $7.19 \pm 0.04$ & $5.85 \pm 0.90$ \\
\hline Electrical conductivity $\left(\mathrm{mS} \mathrm{cm} \mathrm{cm}^{-1}\right)$ & $4.51 \pm 0.08$ & $3.29 \pm 0.08$ & $0.98 \pm 0.91$ \\
\hline Total organic carbon $(\%)$ & $44.70 \pm 1.5$ & $32.20 \pm 1.8$ & $54.20 \pm 1.2$ \\
\hline Total nitrogen $(\%)$ & $2.13 \pm 0.08$ & $1.39 \pm 0.20$ & $0.68 \pm 0.09$ \\
\hline $\mathrm{NH}_{4}^{+}-\mathrm{N}(\%)$ & $1.80 \pm 0.08$ & $0.37 \pm 0.08$ & $0.21 \pm 0.07$ \\
\hline $\mathrm{C}: \mathrm{N}$ ratio & $20.90 \pm 0.3$ & $23.10 \pm 0.4$ & $79.77 \pm 2.1$ \\
\hline Total phosphorous $\left(\mathrm{g} \mathrm{kg}^{-1}\right)$ & $3.15 \pm 0.08$ & $2.52 \pm 0.07$ & $1.25 \pm 0.09$ \\
\hline $\mathrm{Na}\left(\mathrm{g} \mathrm{kg}^{-1}\right)$ & $0.90 \pm 0.08$ & $2.49 \pm 0.05$ & $0.65 \pm 0.07$ \\
\hline $\mathrm{K}\left(\mathrm{g} \mathrm{kg}^{-1}\right)$ & $13.75 \pm 0.50$ & $10.42 \pm 0.31$ & $1.31 \pm 0.15$ \\
\hline $\mathrm{Ca}\left(\mathrm{g} \mathrm{kg}^{-1}\right)$ & $6.31 \pm 0.95$ & $8.92 \pm 0.63$ & $2.94 \pm 0.70$ \\
\hline $\mathrm{Cu}\left(\mathrm{mg} \mathrm{kg}^{-1}\right)$ & $48.62 \pm 0.3$ & $36.24 \pm 0.2$ & $17.82 \pm 0.2$ \\
\hline $\mathrm{Zn}\left(\mathrm{mg} \mathrm{kg}^{-1}\right)$ & $129.53 \pm 1.0$ & $178.22 \pm 1.3$ & $6.21 \pm 1.3$ \\
\hline $\operatorname{Mn}\left(\mathrm{mg} \mathrm{kg}^{-1}\right)$ & $98 \pm 0.8$ & $258 \pm 1.1$ & $56 \pm 1.0$ \\
\hline $\mathrm{Fe}\left(\mathrm{g} \mathrm{kg}^{-1}\right)$ & $1.86 \pm 0.57$ & $1.88 \pm 0.57$ & $0.47 \pm 0.51$ \\
\hline $\operatorname{Mg}\left(\mathrm{g} \mathrm{kg}^{-1}\right)$ & $2.55 \pm 0.19$ & $5.83 \pm 0.15$ & $1.23 \pm 0.12$ \\
\hline
\end{tabular}

$\mathrm{NH}_{4}^{+}-\mathrm{N}$ ammoniacal nitrogen, $\mathrm{C}: \mathrm{N}$ ratio carbon to nitrogen ratio, $\mathrm{Na}$ sodium, $\mathrm{K}$ potassium, $\mathrm{Ca}$ calcium, $\mathrm{Cu}$ copper, $\mathrm{Zn}$ zinc, $\mathrm{Mn}$ manganese, $\mathrm{Fe}$ iron, $\mathrm{Mg}$ magnesium
Table 2 Combination of flower waste, cow dung and saw dust

\begin{tabular}{lcll}
\hline Name of pile & Flower waste $(\mathrm{kg})$ & Cow dung $(\mathrm{kg})$ & Saw dust $(\mathrm{kg})$ \\
\hline$P_{0}$ & 100 & - & - \\
$P_{1}$ & 50 & 40 & 10 \\
$P_{2}$ & 60 & 30 & 10 \\
$P_{3}$ & 70 & 20 & 10 \\
$P_{4}$ & 80 & 10 & 10 \\
\hline
\end{tabular}

chloride method (APHA 2005; Singh and Kalamdhad 2014). The concentrations of $\mathrm{Na}$ and $\mathrm{K}$ were determined

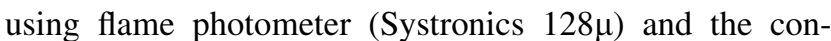
centrations of calcium $(\mathrm{Ca})$, copper $(\mathrm{Cu})$, zinc $(\mathrm{Zn})$, manganese $(\mathrm{Mn})$, iron $(\mathrm{Fe})$, chromium $(\mathrm{Cr})$ and magnesium (Mg) were determined by Inductively Coupled Plasma Atomic Emission Spectroscopy method.

\section{Statistical analysis}

The value of measured Physico-chemical parameters reported for each trial is the mean of duplicate. A one way repeated measure ANOVA was used to test for differences in each of the measured Physico-chemical parameters during composting. SPSS 13.0 was used to perform the analysis of variance (ANOVA $P<0.05$ ) for each parameter among five piles. The objective of statistical analysis was to determine the significant differences among the parameters analyzed for different combinations. Table 3 shows the Anova of physico-chemical parameters.

\section{Results and discussion}

\section{Initial characteristic of waste material}

The initial characteristic of the combination of different waste mixture content piles is shown in Table 1. Flower waste, cow dung and saw dust contained 82.01, 80.10 and $16.71 \%$ of moisture content, respectively. Singh and Kalamdhad (2014) reported that bulking agent regulates moisture content and provides free air passage. In pile $P_{0}(100 \mathrm{~kg})$, flower waste lump formation was observed on the third day and it was possibly due to excess moisture content and lack of air passage between the particles. Leachate production was also observed in pile $P_{0}$. The covering of each pile with plastic sheet helped to increase the temperature inside the pile and it reached the thermophilic phase within one day. Due to the presence of moisture and the action of microbes there was an increase in humidity inside the pile. As a result, vapours were seen on the inner surface of the plastic sheets.

The bacterial activity increased due to the temperature inside the pile and presence of moisture (water) converted this heat into steam. Varma and Kalamdhad (2014b) reported that vapour provided was responsible for the breakdown of tough organic material (lignin or tannin). Turning or proper mixing of piles in every three days provided adequate oxygen to the piles, which reduced the stucking and enhanced the temperature. 
Table 3 Anova of physicochemical parameters

\begin{tabular}{|c|c|c|c|c|c|c|}
\hline Parameters & Anova & Sum of squares & Degree of freedom $(d f)$ & Mean square & $F$ value & $P$ value \\
\hline \multirow[t]{3}{*}{ Electrical conductivity } & Between groups & 75.780 & 4 & 18.945 & 209.660 & 0.0001 \\
\hline & Within groups & 6.777 & 75 & 0.090 & & \\
\hline & Total & 82.557 & 79 & & & \\
\hline \multirow[t]{3}{*}{ Total organic carbon } & Between groups & 279.835 & 4 & 69.959 & 5.004 & 0.001 \\
\hline & Within groups & 1048.604 & 75 & 13.981 & & \\
\hline & Total & 1328.439 & 79 & & & \\
\hline \multirow[t]{3}{*}{$\mathrm{C}: \mathrm{N}$ ratio } & Between groups & 269.943 & 4 & 67.486 & 4.677 & 0.002 \\
\hline & Within groups & 1082.122 & 75 & 14.428 & & \\
\hline & Total & 1352.066 & 79 & & & \\
\hline \multirow[t]{3}{*}{ Ash content } & Between groups & 937.140 & 4 & 234.285 & 5.004 & 0.001 \\
\hline & Within groups & 3511.670 & 75 & 46.822 & & \\
\hline & Total & 4448.810 & 79 & & & \\
\hline \multirow[t]{3}{*}{ Total nitrogen } & Between groups & 0.785 & 4 & 0.196 & 5.115 & 0.001 \\
\hline & Within groups & 2.878 & 75 & 0.038 & & \\
\hline & Total & 3.663 & 79 & & & \\
\hline \multirow[t]{3}{*}{ Sodium } & Between groups & 15.420 & 4 & 3.855 & 21.046 & 0.0001 \\
\hline & Within groups & 13.737 & 75 & 0.183 & & \\
\hline & Total & 29.157 & 79 & & & \\
\hline \multirow[t]{3}{*}{ Potassium } & Between groups & 205.705 & 4 & 51.426 & 54.613 & 0.0001 \\
\hline & Within groups & 70.623 & 75 & 0.942 & & \\
\hline & Total & 276.329 & 79 & & & \\
\hline
\end{tabular}

\section{Temperature}

Temperature is one of the key indicators for active microbial biomass. Figure 1 shows variation of temperature in each pile during the composting process. Each pile attained the mesosphilic phase (Temp $<40{ }^{\circ} \mathrm{C}$ ), thermophilic phase $\left(>45^{\circ} \mathrm{C}\right)$, cooling and maturation phase. However, pile $P_{0}$ could not attain proper thermophilic phase $\left(>45^{\circ} \mathrm{C}\right)$ because of the presence of excess moisture

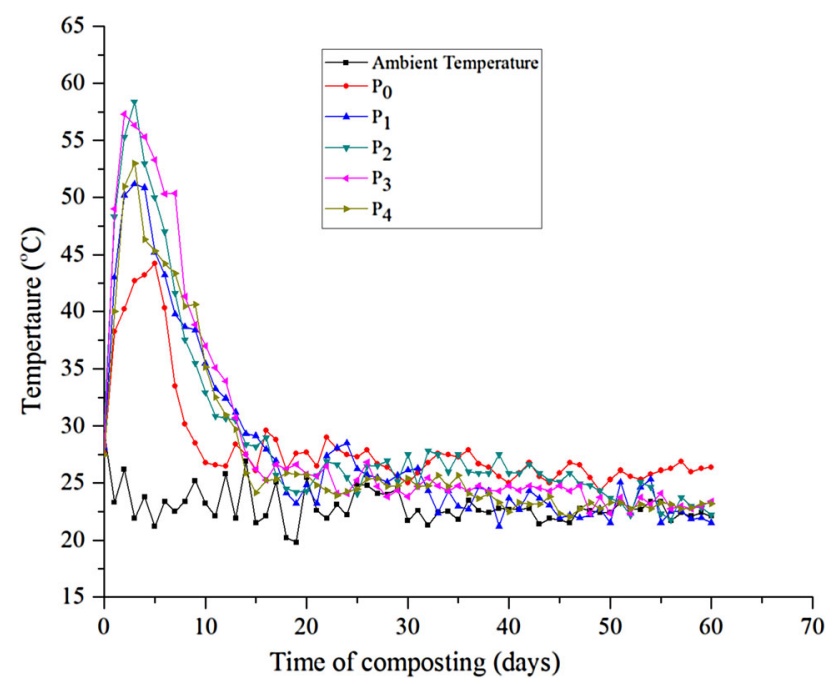

Fig. 1 Variation of temperature during the composting period which was unfavourable for the growth of microbes. Piles $P_{1}$ and $P_{4}$ remained at temperature $>50{ }^{\circ} \mathrm{C}$ for three and two days, respectively. Piles $P_{2}$ and $P_{3}$ remained at $>50{ }^{\circ} \mathrm{C}$ for 4 and 6 days, respectively. Maximum thermophilic phase was observed in piles $P_{2}$ and $P_{3}$ due to the proper combination of flower waste and cow dung. The presence of higher and lower proportion of waste mixture was responsible for the duration of thermophilic phase and for achieving maximum temperature. The maximum temperature recorded in piles $P_{2}$ and $P_{3}$ was 58.40 and $57.32{ }^{\circ} \mathrm{C}$, respectively. Temperature between 50 and $60{ }^{\circ} \mathrm{C}$ for two consecutive days kills the pathogens and this sanitizes the compost (Awasthi et al. 2015). For each pile, the observation was that within 15 days the temperature became near to the ambient temperature. Similar variations of temperature were reported by Abdullah et al. (2013), Singh and Kalamdhad (2014), Varma and Kalamdhad (2014b) for the composting of different organic waste.

\section{Moisture content}

Figure 2 illustrates moisture content variations in each pile. Initial moisture content of piles $P_{0}, P_{1}, P_{2}, P_{3}$ and $P_{4}$ were $82.0 \pm 2.68 \%, \quad 72.5 \pm 3.01 \%, \quad 73.7 \pm 2.92 \%, \quad 76.7 \pm$ $3.21 \%, 81.2 \pm 2.87 \%$, respectively. Moisture content decreases linearly in $P_{1}, P_{2}, P_{3}$ and $P_{4}$. Whereas increase in moisture content and formation of leachate was observed in 
$P_{0}$, decrease in moisture content was primarily because of the use of saw dust, which absorbed excess moisture, and thus maintained moisture content, whereas in absence of bulking agent, moisture content increased. Simultaneously, with the increase of cow dung, decrease in temperature was observed. Cow dung provides microbial inoculums which enhances microbial activity resulting in increasing the rate of degradation of organic matter. $P_{1}$ and $P_{4}$ took more time because of the presence of ratio of cow dung and flower waste i.e. 4:5 and 1:8, respectively. This indicates that the ratio of cow dung and flower waste significantly affects the composting and the adequate ratio must be maintained.

\section{pH and Electrical conductivity (EC)}

Figure 3 shows the variation in $\mathrm{pH}$ and electrical conductivity during composting. The increase in $\mathrm{pH}$ value was observed for the first 15 days and later a slight variation in $\mathrm{pH}$ value was observed for the next 15 days (15-30 days). After 30 days, $\mathrm{pH}$ of compost was stabilized at $7.5 \pm 1.2$ in each pile. The increase in $\mathrm{pH}$ was mainly due to the regular turning process which assists in maintaining adequate oxygen to keep aerobic condition (Awasthi et al. 2015).

The neutral $\mathrm{pH}$ value was observed after the 12th day as flower waste contained high water soluble $\mathrm{K}$ concentration which reacts with bi-carbonic acid $\left(\mathrm{HCO}_{3}{ }^{-}\right)$during the degradation of organic matter to form strong base $\mathrm{KOH}$. The buffering capacity of humus and volatilization of ammonia result in a slight decrease in $\mathrm{pH}$ value. Similar results were reported for organic waste composting (Kalamdhad and Kazmi 2009; Mena et al. 2003). The final $\mathrm{pH}$ value between 6 and 8 shows the maturity of the compost (Varma and Kalamdhad 2014a).

Electrical conductivity represents the salinity of compost. The range of EC into compost is $0.14-12 \mathrm{mS} \mathrm{cm}^{-1}$ which is

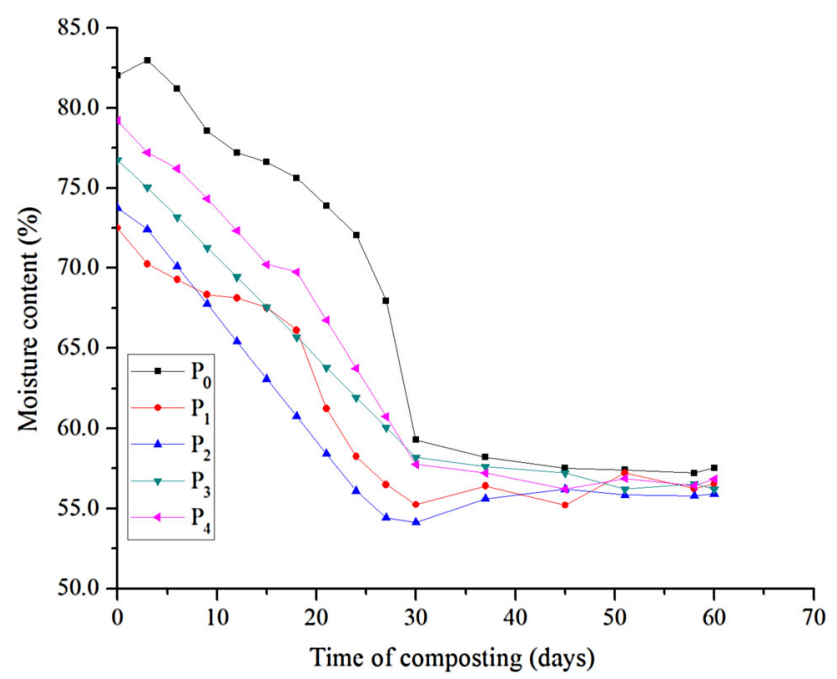

Fig. 2 Variation of moisture content during the composting period suitable for the growth of plants (Huang et al. 2004). Initial low value in electrical conductivity in waste composition shows the suitability of flower waste for composting. It was observed that the increased electrical conductivity in the beginning of thermophilic phase became stable in cooling phase. However, this behaviour was not observed in pile $P_{0}$ where electrical conductivity increased. The degradation of organic matter took place in the beginning of the thermophilic phase which released mineral salts such as ammonium and phosphate and that increased the electrical conductivity. Stabilized electrical conductivity value attributes to the volatilization of mineral salts (Yadav et al. 2013). Inspite of electrical conductivity value in between 0.12 and12.2 $\mathrm{mS} \mathrm{cm}{ }^{-1}$ in $P_{0}$, it did not indicate quality compost due to the high moisture content and the low temperature which influence the degradation of the organic matter.

\section{Total organic carbon (TOC), ash content and ammoniacal nitrogen $\left(\mathrm{NH}_{4}{ }^{+}-\mathrm{N}\right)$}

Changes in carbon concentration indicate compost maturity. Higher rate of carbon content degradation indicates stabilized compost at the end of the composting. Variation of total organic carbon is shown in Fig. 4a. Reduction of total organic carbon at the end of composting in piles $P_{0}, P_{1}, P_{2}$, $P_{3}$ and $P_{4}$ were 13.5, 24.5, 29.6, 30.9 and 22.4\%, respectively. The low reduction of total organic carbon in $P_{0}$ was due to unavailability of inoculum such as cow dung and the absence of temperature $>50{ }^{\circ} \mathrm{C}$. Pile $P_{1}$ had easily digestible organic substrate for microbes. This reduction in total organic carbon was higher than that of $P_{4}$. The percentage reduction of total organic carbon in $P_{2}$ and $P_{3}$ was higher due to the availability of thermophilic bacteria which enhances the degradation rate of complex cellulose and protein. A similar result in the reduction of total organic carbon in organic waste was reported in the literature (Awasthi et al. 2015; Zhou et al. 2014). The reduction of the total organic carbon content indicates the mineralization of the organic matter and the maturity of the compost.

Figure $4 \mathrm{~b}$ shows the variation of ash contents during the composting period. Initially the presence of ash content in pile $P_{0}, P_{1}, P_{2}, P_{3}$ and $P_{4}$ were $18.65 \pm 2.63,19.44 \pm$ $3.12,19.51 \pm 2.75,17.26 \pm 1.95$ and $17.39 \pm 2.75 \%$, respectively, which was increased, respectively, to $29.70 \pm 3.11,39.22 \pm 2.42,43.37 \pm 1.58,42.90 \pm 1.75$ and $35.95 \pm 2.35 \%$ at the end of composting period. Higher rate of increase in ash contents was observed in pile $P_{2}$ (6:3:1) ratio of waste mixture due to the higher rate of degradation of organic matter at the time of thermophilic phase. In pile $P_{0}$, the increase in percentage of ash content was less as compared to the pile containing cow dung and saw dust due to lower temperature and presence of higher moisture content. 
Fig. 3 Variation of $\mathrm{pH}$ and electrical conductivity during composting period

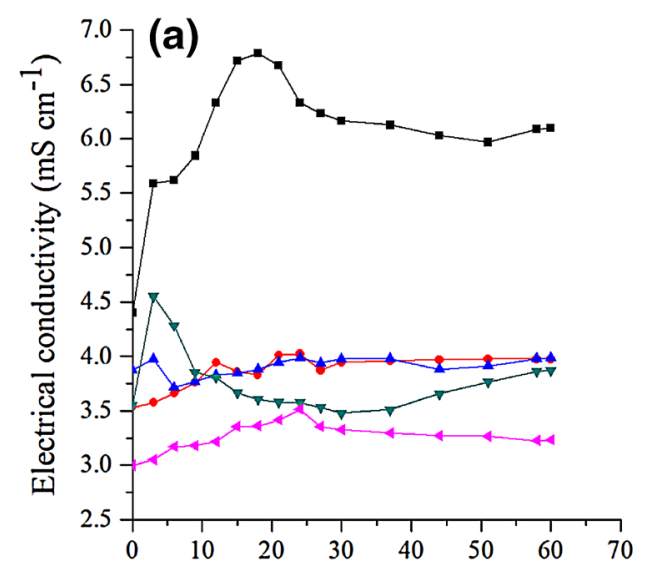

$-\mathrm{P}_{0} \rightarrow-\mathrm{P}_{1} \nrightarrow-\mathrm{P}_{2} \rightarrow-\mathrm{P}_{3} \leftarrow \mathrm{P}_{4}$

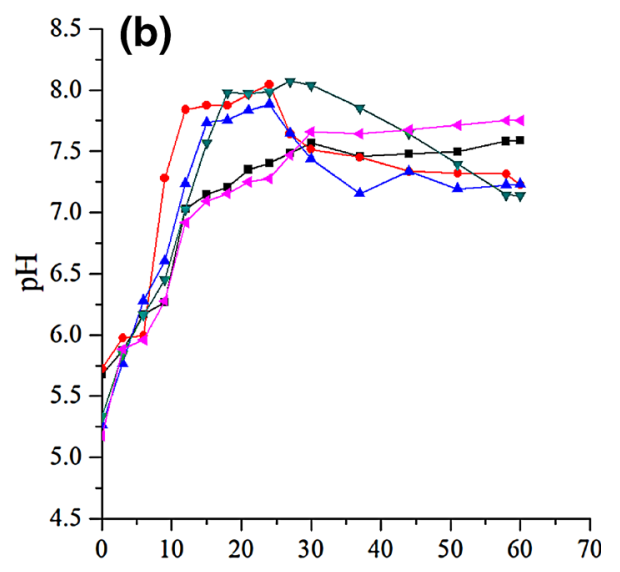

Time of composting (days)
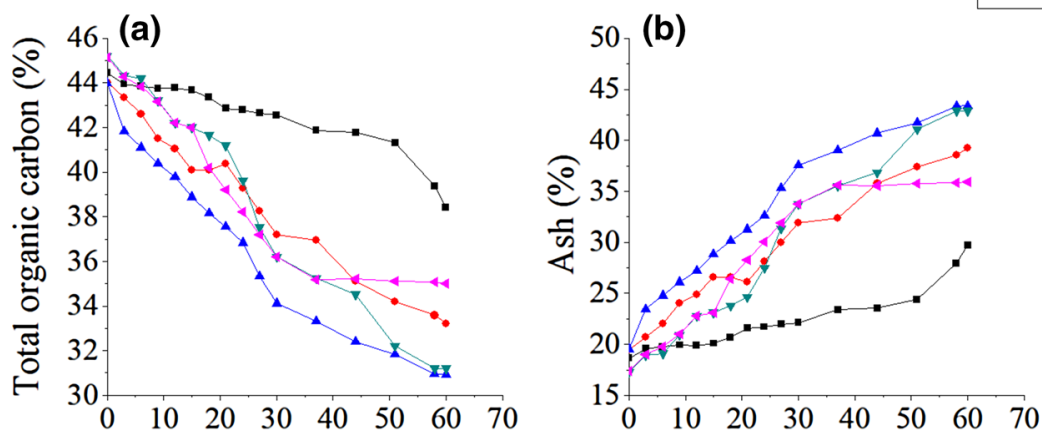

$\because \mathrm{P}_{0} \rightarrow \mathrm{P}_{1} \longleftarrow \mathrm{P}_{2} \multimap \mathrm{P}_{3} \longleftarrow \mathrm{P}_{4}$

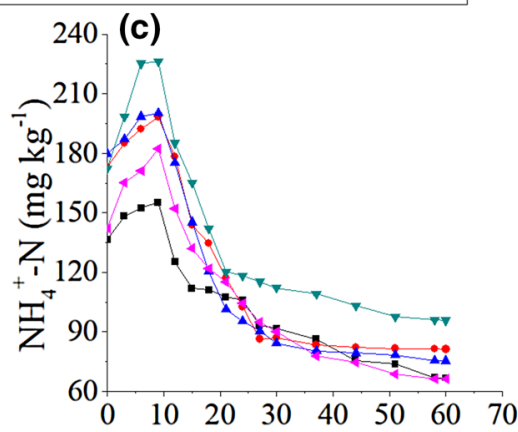

Time of composting (days)

Fig. 4 Variation of total organic carbon ash content and ammoniacal nitrogen during composting period

Figure $4 \mathrm{c}$ shows the variation of ammoniacal nitrogen during the composting period. It was observed that in $P_{0}$ the ammoniacal nitrogen reduction was high when compared to other piles. This may be due to the low temperature in thermophilic phase and low degradation rate of the organic matter. In piles $P_{1}, P_{2}, P_{3}$ and $P_{4}$ the initial ammoniacal nitrogen were $73.0 \pm 21.3,179.8 \pm 19.5,172.3 \pm 21.5$ and $142.2 \pm 16.5 \mathrm{mg} \mathrm{kg}^{-1}$, respectively, which finally decreased to $81.8 \pm 23.2,75.3 \pm 24.5,95.8 \pm 19.5$ and $66.4 \pm 18.9 \mathrm{mg} \mathrm{kg}^{-1}$, respectively, during composting. The ammoniacal nitrogen concentration decreased due to the volatilization of $\mathrm{NH}_{4}{ }^{+}-\mathrm{N}$ by the microbes and the nitrification during the composting process.

\section{Macro nutrients (N, P, K, Na, Ca and Mg) and micro nutrients (Fe, $\mathrm{Mn}, \mathrm{Zn}$ and $\mathrm{Cu}$ )}

The Macro nutrients in the organic matter are used by the microbes for body metabolism and also for the growth of plants. Figure 5a shows the variation of total nitrogen content. The initial concentration of total nitrogen in piles $P_{0}-P_{4}$ was between at 1.6 and $1.7 \%$ and increased to concentrations of $2.2-2.3 \%$ at the end of the composting process. The increasing trends of total nitrogen in this study was found to be similar to results by Jolanun and Towprayoon (2010). Total nitrogen increased due to the degradation of organic matter and loss of carbon in the form of $\mathrm{CO}_{2}$ and the contribution of nitrogen fixing bacteria which were the responsible for the increase of total nitrogen content (Garcia et al. 1992).

Figure $5 \mathrm{~b}$ shows the increase in concentration of sodium from the initial to the final day of composting. Initial concentrations of sodium in piles $P_{0}-P_{4}$ were 2.5-3.2 $\mathrm{g} \mathrm{kg}^{-1}$ which increased to $5.3-4.9 \mathrm{~g} \mathrm{~kg}^{-1}$ within the 60 days composting period. The concentration of macronutrients $\mathrm{P}, \mathrm{K}, \mathrm{Na}, \mathrm{Ca}$ and $\mathrm{Mg}$ increased gradually which indicates the net loss in dry mass due to the degradation of organic matter and the release of $\mathrm{CO}_{2}, \mathrm{NH}_{3}$ and $\mathrm{H}_{2} \mathrm{~S}$ during the composting process (Bustamante et al. 2009). 
Fig. 5 Variation of total nitrogen, sodium, potassium, phosphorous during composting period
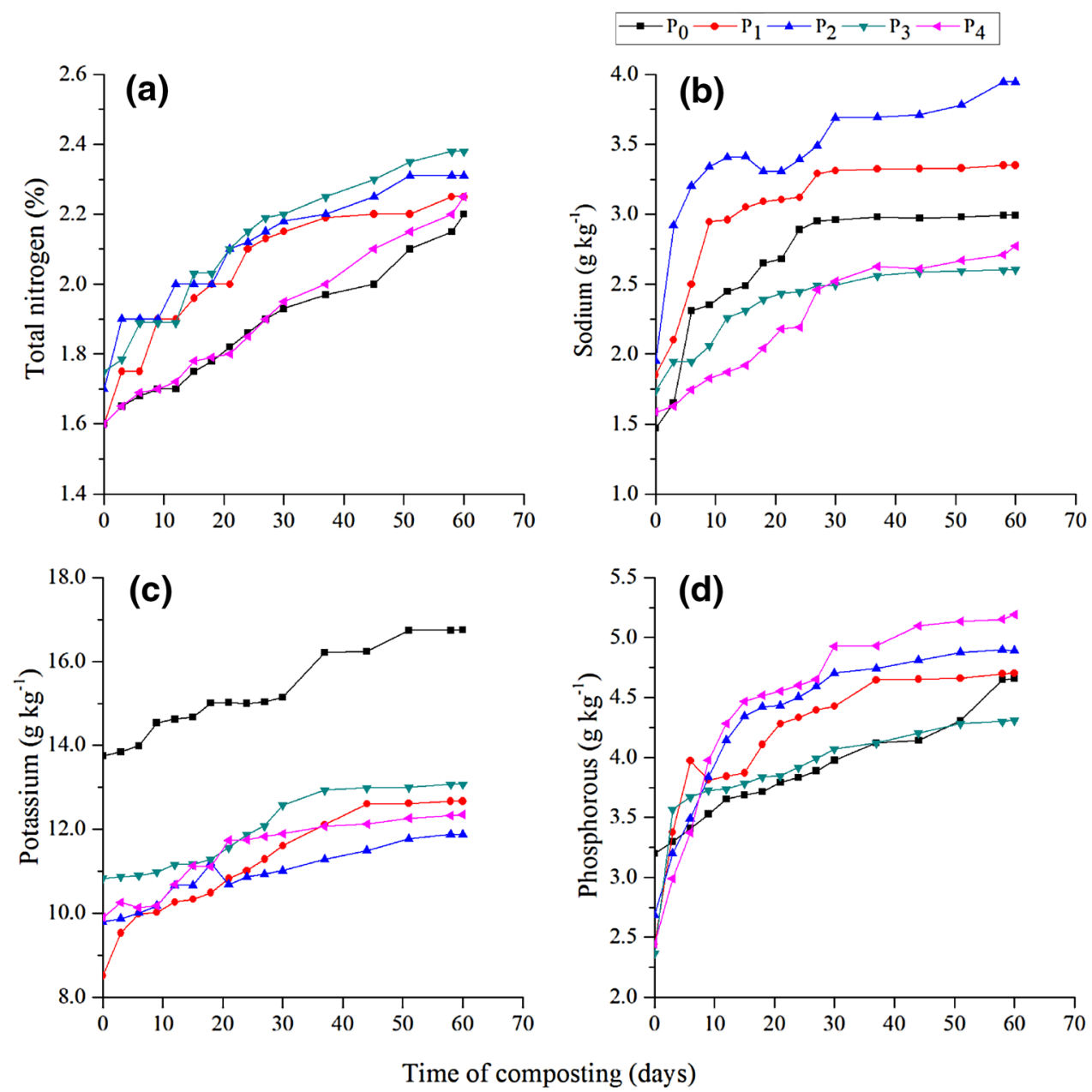

Initial total phosphorous content in the pile $P_{0}$ was $3.20 \pm 0.09 \mathrm{~g} \mathrm{~kg}^{-1}$, which finally increased to $4.65 \pm 1.23 \mathrm{~g} \mathrm{~kg}^{-1}$. In $P_{1}, P_{2}, P_{3}$ and $P_{4}$ the initial content of phosphorous were $2.44 \pm 0.32, \quad 2.69 \pm 0.12$, $2.37 \pm 0.89$ and $2.45 \pm 0.85 \mathrm{~g} \mathrm{~kg}^{-1}$, which increased, respectively, to $4.70 \pm 0.12,4.89 \pm 0.52,4.31 \pm 0.74$ and $5.19 \pm 0.95 \mathrm{~g} \mathrm{~kg}^{-1}$ at the end of the composting process. The order of increase of the presence of phosphorous content in the piles was $P_{4}>P_{2}>P_{1}>P_{0}>P_{3}$. The increase in phosphorus concentration during composting can be attributed to the loss of organic matter. Similar increase in phosphorous content was observed by Singh and Kalamdhad (2014), Varma and Kalamdhad (2014b) during the composting of water hyacinth and vegetable waste.

Initial concentration of potassium in pile $P_{0}$ was $13.75 \pm 0.50 \mathrm{~g} \mathrm{~kg}^{-1}$ and it increased to $16.75 \pm$ $0.82 \mathrm{~g} \mathrm{~kg}^{-1}$ in 60 days. The concentration of potassium was rich in pile $P_{0}$. It shows the high inherent content in flower waste, suggesting that the compost is rich in potassium. The Initial potassium concentrations in piles $P_{1}, P_{2}, P_{3}$ and $P_{4}$ were $13.7 \pm 0.54,8.5 \pm 1.2,9.7 \pm 0.94,10.8 \pm 0.63$ and $9.9 \pm 0.54 \mathrm{~g} \mathrm{~kg}^{-1}$, and, respectively, increased to
$16.7 \pm 0.85,12.6 \pm 1.25,11.8 \pm 1.34,13.0 \pm 1.54$ and $12.3 \pm 1.24 \mathrm{~g} \mathrm{~kg}^{-1}$ at the end of the composting period. The increase in potassium concentration in all the piles is partly due to potassium assimilation and immobilisation by microbes (Singh and Kalamdhad 2012).

Micronutrients present in small amounts in the compost help in the growth of the plant and in plant reproduction (Wang et al. 2004). Manganese helps in nitrogen assimilation and photosynthesis in plant. Zinc helps in the secretion of enzymes and protein synthesis which regulate the growth of plants. Copper and iron help in the metabolism process of the plants. The initial and final concentration of micronutrient $\mathrm{Fe}, \mathrm{Mn}, \mathrm{Zn}$ and $\mathrm{Cu}$ present in the compost is shown in Table 4. In all the piles, an increase in micronutrients contents was observed. The increment order of micronutrient present on the final day of compost was $\mathrm{Fe}>\mathrm{Mn}>\mathrm{Zn}>\mathrm{Cu}$.

The concentration of iron in $P_{0} 8.6 \pm 0.49 \mathrm{~g} \mathrm{~kg}^{-1}$ was the highest due to the high iron content in flower waste. Initially the concentration of manganese in pile $P_{1}$ was more compared to the remaining piles. The concentration of manganese in cow dung and flower waste was $98 \pm 0.8$ 
Table 4 Macro and microelement contents in the initial and final day of the composting period

\begin{tabular}{|c|c|c|c|c|c|c|}
\hline Elements & Day & Pile 0 & Pile 1 & Pile 2 & Pile 3 & Pile 4 \\
\hline \multirow[t]{2}{*}{$\mathrm{Ca}\left(\mathrm{g} \mathrm{kg}^{-1}\right)$} & 0 & $6.43 \pm 0.77$ & $10.66 \pm 0.51$ & $9.12 \pm 1.37$ & $7.83 \pm 0.46$ & $8.11 \pm 0.88$ \\
\hline & 60 & $16.49 \pm 0.76$ & $29.67 \pm 1.04$ & $25.98 \pm 0.50$ & $18.09 \pm 1.85$ & $15.92 \pm 1.03$ \\
\hline \multirow[t]{2}{*}{$\operatorname{Mg}\left(\mathrm{g} \mathrm{kg}^{-1}\right)$} & 0 & $2.27 \pm 0.02$ & $3.55 \pm 0.04$ & $3.2 \pm 0.01$ & $2.83 \pm 0.03$ & $2.47 \pm 0.01$ \\
\hline & 60 & $6.86 \pm 0.02$ & $6.53 \pm 0.01$ & $5.22 \pm 0.02$ & $6.05 \pm 0.03$ & $5.87 \pm 0.02$ \\
\hline \multirow[t]{2}{*}{$\mathrm{Fe}\left(\mathrm{g} \mathrm{kg}^{-1}\right)$} & 0 & $0.92 \pm 0.46$ & $1.64 \pm 0.46$ & $1.58 \pm 0.52$ & $1.57 \pm 0.43$ & $1.03 \pm 0.20$ \\
\hline & 60 & $8.69 \pm 0.49$ & $6.8 \pm 0.48$ & $4.69 \pm 0.33$ & $6.77 \pm 0.25$ & $7.53 \pm 1.01$ \\
\hline \multirow[t]{2}{*}{$\operatorname{Mn}\left(\mathrm{mg} \mathrm{kg}^{-1}\right)$} & 0 & $99.63 \pm 1.63$ & $208.36 \pm 0.50$ & $143.17 \pm 1.1$ & $126.43 \pm 0.70$ & $110.24 \pm 1.0$ \\
\hline & 60 & $126.36 \pm 2.0$ & $244.42 \pm 0.50$ & $171.32 \pm 1.0$ & $170.1 \pm 1.12$ & $152.71 \pm 0.5$ \\
\hline \multirow[t]{2}{*}{$\mathrm{Zn}\left(\mathrm{mg} \mathrm{kg}^{-1}\right)$} & 0 & $127.29 \pm 1.0$ & $130.76 \pm 0.50$ & $177.11 \pm 1.1$ & $152.99 \pm 0.50$ & $141.78 \pm 0.5$ \\
\hline & 60 & $163.77 \pm 0.7$ & $177.42 \pm 0.80$ & $204.88 \pm 0.3$ & $192.06 \pm 0.50$ & $176.13 \pm 0.7$ \\
\hline \multirow[t]{2}{*}{$\mathrm{Cu}\left(\mathrm{mg} \mathrm{kg}^{-1}\right)$} & 0 & $36.42 \pm 0.08$ & $39.76 \pm 0.11$ & $38.18 \pm 0.18$ & $37.12 \pm 0.12$ & $35.11 \pm 0.11$ \\
\hline & 60 & $48.14 \pm 0.14$ & $40.6 \pm 0.25$ & $42.73 \pm 0.15$ & $43.21 \pm 0.03$ & $45.26 \pm 0.03$ \\
\hline
\end{tabular}

$\mathrm{Ca}$ calcium, $\mathrm{Mg}$ magnesium, $\mathrm{Fe}$ iron, $\mathrm{Mn}$ manganese, $\mathrm{Zn}$ zinc, $\mathrm{Cu}$ copper

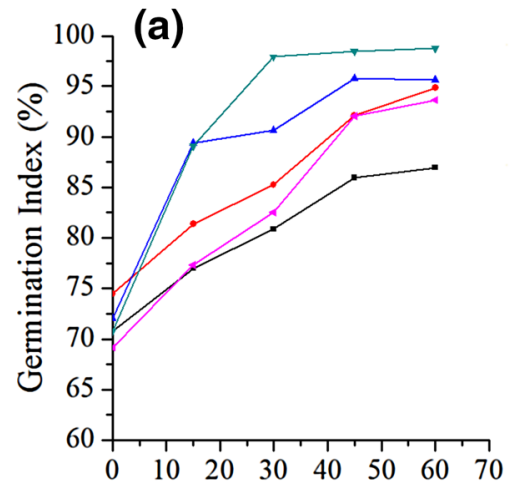

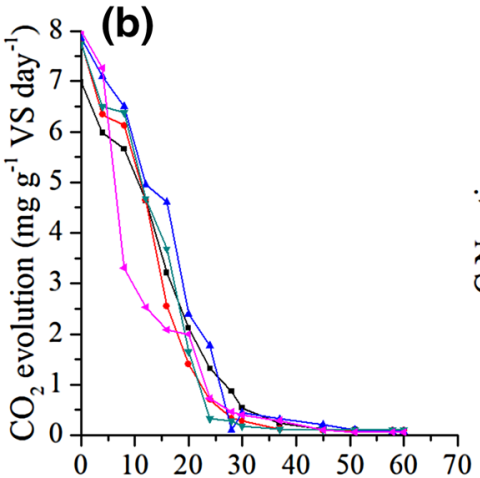

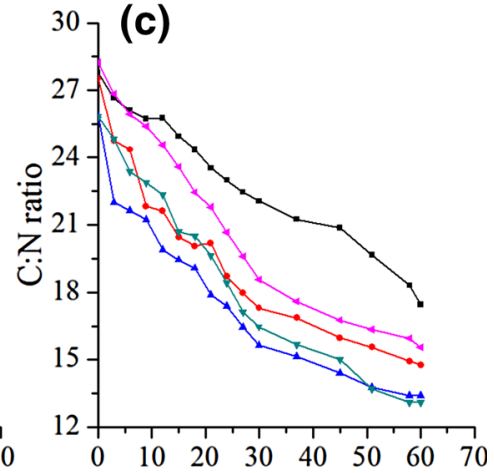

Time of composting (days)

Fig. 6 Variation of germination index, $\mathrm{CO}_{2}$ evolution rate, $\mathrm{C}: \mathrm{N}$ ratio

and $258 \pm 1.1 \mathrm{mg} \mathrm{kg}^{-1}$, respectively. The increase in magnesium content in pile $P_{1}$ was due to increased quantity of cow dung. The concentration of zinc in pile $P_{2}$ was comparatively more than the remaining piles. This was due to the availability of zinc content in the flower waste $129 \pm 1 \mathrm{mg} \mathrm{kg}^{-1}$ and cow dung $178 \pm 1.3 \mathrm{mg} \mathrm{kg}^{-1}$. The concentration of copper was more in the flower waste $48.62 \pm 0.3 \mathrm{mg} \mathrm{kg}^{-1}$ whereas in cow dung it was $36.24 \pm 0.2 \mathrm{mg} \mathrm{kg}^{-1}$. The concentration of copper in pile $P_{0}$ was observed as $48.14 \pm 0.14 \mathrm{mg} \mathrm{kg}^{-1}$ on the final day of composting. This study showed that the flower waste was rich in macro and micronutrients which are essential for the plants. The addition of cow dung helps in fast microbial activities. In each pile, it was observed that at the end of composting the concentration of micronutrients had increased due to the degradation of organic matter and the release of ammonia.

\section{Germination index (GI), $\mathrm{C}$ : $\mathbf{N}$ ratio and carbon dioxide $\left(\mathrm{CO}_{2}\right)$ evolution}

Germination index is necessary for the determination of maturity and phytotoxicity effects of compost (Gao et al. 2010; Huang et al. 2004). Germination index is widely used to check the suitability of compost for agricultural purposes. Figure $6 a$ shows the germination index during the composting process of flower waste. The germination index which was initially $70,74,72,70$ and $69 \%$ in piles $P_{0}-P_{4}$ were increased to $86,94,95,98$ and $93 \%$, respectively, at the end of the composting period. The germination index was more than $50 \%$ which shows that flower waste compost is a good source for the growth of plants. Zhang and Sun (2015) concluded that the optimum percentage of germination index suitable for mature compost is more than $50 \%$. Similar trends of germination index 
were observed by Gao et al. (2010) and Singh et al. (2013) during composting of different proportions of organic waste.

$\mathrm{CO}_{2}$ evolution is one of the best methods to determine the stability of the compost because it measures the carbon derived directly from decomposition or degradation of the organic matter. $\mathrm{CO}_{2}$ evolution directly synthesizes aerobic respiration, which shows the direct measure of respiration and aerobic microbial activity (Kalamdhad and Kazmi 2009). $\mathrm{CO}_{2}$ production decreased with time. Figure $6 \mathrm{~b}$ depicts that the $\mathrm{CO}_{2}$ production in piles $P_{1}-P_{4}$ was $6.9,7.7$, 7.6, 7.4 and $7.9 \mathrm{mg} \mathrm{g}^{-1} \mathrm{VS} \mathrm{day}^{-1}$ which decreased to 0.5 , $0.2,0.4,0.1$ and $0.3 \mathrm{mg} \mathrm{g}^{-1} \mathrm{VS} \mathrm{day}^{-1}$, respectively, during the composting process. Similar decreasing trends of $\mathrm{CO}_{2}$ production rate was observed by Varma and Kalamdhad (2014b) during the rotary drum composting of vegetable waste.

Figure 6c shows the variation of $\mathrm{C}: \mathrm{N}$ ratio during the composting process. C:N ratio is a widely used parameter to indicate the maturity of the compost (Huang et al. 2004; Jiang et al. 2011). The initial C:N ratio of pile $P_{0}$ was 28 which reduced to 18 at the end of the composting period. The reduction in C:N ratio was due to the reduction of total organic carbon and increase of total nitrogen during the composting period. The initial C:N ratio of pile $P_{1}-P_{4}$ was 26-28 and it decreased to 14-16 at the end of composting period. The reduction of $\mathrm{C}: \mathrm{N}$ ratio was due to the usage of carbon as a source of energy by the microorganisms while nitrogen was used for building the cell structure by the different group of microbes (Adhikari et al. 2009; Yadav et al. 2011; Yadav and Garg 2009). In $P_{2}$, due to fast degradation of cow dung, a $24.5 \%$ reduction of the C:N ratio was observed without reducing the carbon content, which indicates the quality of the matured compost. In pile $P_{0}$, due to rich content of flower waste and the absence of saw dust and cow dung, less reduction in total organic carbon content and an increase in the total nitrogen content was observed, all of which resulted in an increased $\mathrm{C}: \mathrm{N}$ ratio. This research shows that the addition of cow dung plays an important role in the reduction of the total organic carbon and the duration of composting process.

\section{Conclusions}

A conclusion that the study derived is that the agitated pile composting of flower waste with cow dung and saw dust as bulking agent resulted in completely stabilized compost at the end of sixty days. The study also reported the leachate production during the process due to the absence of saw dust. The maximum degradation of organic matter was observed during the first 30 days of the composting process. The addition of the bulking agent helped in maintaining the aerobic condition, which reduced the excessive formation of leachate and maintained the thermophilic stage for a longer period. Macro and micronutrients contents after composting were observed in suitable ranges for agricultural purposes. The physicochemical analysis showed that the pile containing $60 \mathrm{~kg}$ of flower waste, $30 \mathrm{~kg}$ of cow dung, and $10 \mathrm{~kg}$ of saw dust would be the most appropriate combination for the composting of flower waste.

Open Access This article is distributed under the terms of the Creative Commons Attribution 4.0 International License (http://crea tivecommons.org/licenses/by/4.0/), which permits unrestricted use, distribution, and reproduction in any medium, provided you give appropriate credit to the original author(s) and the source, provide a link to the Creative Commons license, and indicate if changes were made.

\section{References}

Abdullah N, Chin NL, Mokhtar MN, Taip FS (2013) Effects of bulking agents, load size or starter cultures in kitchen-waste composting. Int J Recycl Org Waste Agric 2:1-10. doi:10.1186/ 2251-7715-2-3

Adhikari BK, Barrington S, Martinez J, King S (2009) Effectiveness of three bulking agents for food waste composting. Waste Manag 29:197-203. doi:10.1016/j.wasman.2008.04.001

APHA (2005) Standard methods for the examination of water and wastewater, 20th edn. American Public Health Association Washington. https://www.standardmethods.org/

Awasthi MK, Pandey AK, Bundela PS, Khan J (2015) Co-composting of organic fraction of municipal solid waste mixed with different bulking waste: characterization of physicochemical parameters and microbial enzymatic dynamic. Bioresour Technol 182:200-207. doi:10.1016/j.biortech.2015.01.104

Ball AS, Shah D, Wheatley CF (2000) Assessment of the potential of a novel newspaper/horse manure-based compost. Bioresour Technol 73:163-167. doi:10.1016/S0960-8524(99)00169-8

BIS (1982) Methods for analysis of solid wastes (excluding industrial solid wastes). Indian Standard Institution, New Delhi. https:// www.bis.org.in/

Bustamante M, Paredes C, Morales J, Mayoral A, Moral R (2009) Study of the composting process of winery and distillery wastes using multivariate techniques. Bioresour Technol 100:4766-4772. doi:10.1016/j.biortech.2009.04.033

Gao M, Li B, Yu A, Liang F, Yang L, Sun Y (2010) The effect of aeration rate on forced-aeration composting of chicken manure and sawdust. Bioresour Technol 101:1899-1903. doi:10.1016/j. biortech.2009.10.027

Garcia C, Hernandez T, Costa F, Ayuso M (1992) Evaluation of the maturity of municipal waste compost using simple chemical parameters. Commun Soil Sci Plant Anal 23:1501-1512. doi:10. 1080/00103629209368683

Huang G, Wong J, Wu Q, Nagar B (2004) Effect of C/N on composting of pig manure with sawdust. Waste Manag 24:805-813. doi:10.1016/j.wasman.2004.03.011

Iyengar SR, Bhave PP (2006) In-vessel composting of household wastes. Waste Manag 26:1070-1080. doi:10.1016/j.wasman.2005.06.011

Jiang T, Schuchardt F, Li G, Guo R, Zhao Y (2011) Effect of C/N ratio, aeration rate and moisture content on ammonia and greenhouse gas emission during the composting. J Environ Sci 23:1754-1760. doi:10.1016/S1001-0742(10)60591-8 
Jolanun B, Towprayoon S (2010) Novel bulking agent from clay residue for food waste composting. Bioresour Technol 101:4484-4490. doi:10.1016/j.biortech.2010.01.116

Kalamdhad AS, Kazmi A (2009) Effects of turning frequency on compost stability and some chemical characteristics in a rotary drum composter. Chemosphere 74:1327-1334. doi:10.1016/j. chemosphere.2008.11.058

Mena E, Garrido A, Hernandez T, Garcia C (2003) Bioremediation of sewage sludge by composting. Commun Soil Sci Plant Anal 34:957-971. doi:10.1081/CSS-120019102

Sánchez-Monedero M, Roig A, Paredes C, Bernal M (2001) Nitrogen transformation during organic waste composting by the Rutgers system and its effects on $\mathrm{pH}, \mathrm{EC}$ and maturity of the composting mixtures. Bioresour Technol 78:301-308. doi:10.1016/S09608524(01)00031-1

Singh J, Kalamdhad AS (2012) Concentration and speciation of heavy metals during water hyacinth composting. Bioresour Technol 24:169-179. doi:10.1016/j.biortech.2012.08.043

Singh WR, Kalamdhad AS (2014) Potential for composting of green phumdi biomass of Loktak lake. Ecol Eng 67:119-126. doi:10. 1016/j.ecoleng.2014.03.086

Singh J, Kalamdhad AS (2015) Assessment of compost quality in agitated pile composting of water hyacinth collected from different sources. Int J Recycl Org Waste Agric 4:175-183. doi:10.1007/s40093-015-0097-z

Singh WR, Kalamdhad AS (2016) Transformation of nutrients and heavy metals during vermicomposting of the invasive green weed Salvinia natans using Eisenia fetida. Int $\mathrm{J}$ Recycl Org Waste Agric, pp 1-16 doi:10.1007/s40093-016-0129-3

Singh A, Jain A, Sarma BK, Abhilash P, Singh HB (2013) Solid waste management of temple floral offerings by vermicomposting using Eisenia fetida. Waste Manag 33:1113-1118. doi:10.1016/j. wasman.2013.01.022

Varma VS, Kalamdhad A (2014a) Evolution of chemical and biological characterization during thermophilic composting of vegetable waste using rotary drum composter. Int $\mathbf{J}$ Environ Sci Technol, pp 1-10. doi:10.1007/s13762-014-0582-3

Varma VS, Kalamdhad AS (2014b) Stability and microbial community analysis during rotary drum composting of vegetable waste. Int $\mathbf{J}$ Recycl Org Waste Agric 3:1-9. doi:10.1007/s40093-014-0052-4
Wang P, Changa C, Watson M, Dick W, Chen Y, Hoitink H (2004) Maturity indices for composted dairy and pig manures. Soil Biol Biochem 36:767-776. doi:10.1016/j.soilbio.2003.12.012

Wang L-P, Shen Q-R, Yu G-H, Ran W, Xu Y-C (2012) Fate of biopolymers during rapeseed meal and wheat bran composting as studied by two-dimensional correlation spectroscopy in combination with multiple fluorescence labeling techniques. Bioresour Technol 105:88-94. doi:10.1016/j.biortech.2011.11.064

Wang K, Li X, He C, Chen C-L, Bai J, Ren N, Wang J-Y (2014) Transformation of dissolved organic matters in swine, cow and chicken manures during composting. Bioresour Technol 168:222-228. doi:10.1016/j.biortech.2014.03.129

Wu C, Li W, Wang K, Li Y (2015) Usage of pumice as bulking agent in sewage sludge composting. Bioresour Technol 190:516-521. doi:10.1016/j.biortech.2015.03.104

Yadav A, Garg VK (2009) Feasibility of nutrient recovery from industrial sludge by vermicomposting technology. J Hazard Mater 168:262-268. doi:10.1016/j.jhazmat.2009.02.035

Yadav KD, Tare V, Ahammed MM (2011) Vermicomposting of source-separated human faeces by Eisenia fetida: effect of stocking density on feed consumption rate, growth characteristics and vermicompost production. Waste Manag 31:1162-1168. doi:10.1016/j.wasman.2011.02.008

Yadav A, Gupta R, Garg VK (2013) Organic manure production from cow dung and biogas plant slurry by vermicomposting under field conditions. Int J Recycl Org Waste Agric 2:21. doi:10.1186/ 2251-7715-2-21

Zhang L, Sun X (2015) Influence of bulking agents on physical, chemical, and microbiological properties during the two-stage composting of green waste. Waste Manag 48:115-126. doi:10. 1016/j.wasman.2015.11.032

Zhou Y, Selvam A, Wong JW (2014) Evaluation of humic substances during co-composting of food waste, sawdust and Chinese medicinal herbal residues. Bioresour Technol 168:229-234. doi:10.1016/j.biortech.2014.05.070 